\title{
'They came from the ends of the earth': long-distance exchange of obsidian in the High Arctic during the Early Holocene
}

Vladimir V. Pitulko, ${ }^{1,}$, Yaroslav V. Kuzmin ${ }^{2,3,{ }^{*}}$, Michael D. Glascock ${ }^{4}$, Elena Yu. Pavlova ${ }^{5} \&$ Andrei V. Grebennikov ${ }^{6,7}$

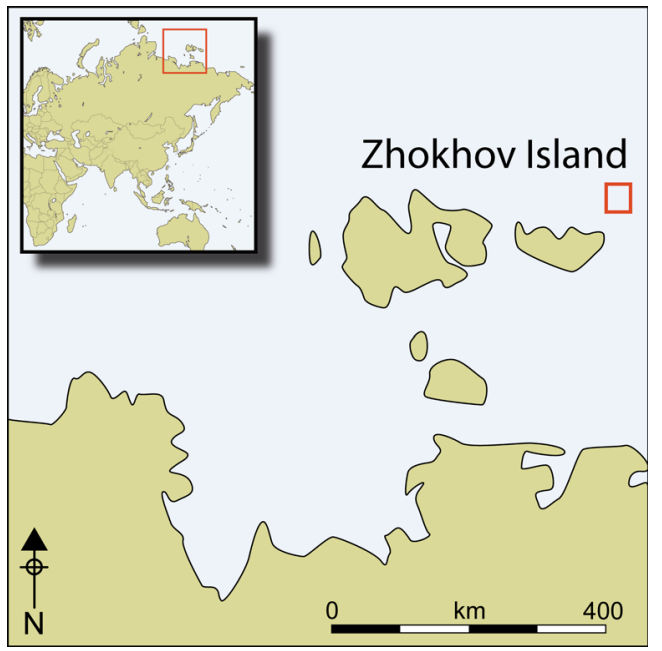

Zhokhov Island in the Siberian High Arctic has yielded evidence for some of the most remote prehistoric human occupation in the world, as well as the oldest-known dog-sled technology. Obsidian artefacts found on Zhokhov have been provenanced using XRF analysis to allow comparison with known sources of obsidian from north-eastern Siberia. The results indicate that the obsidian was sourced from Lake Krasnoeapproximately $1500 \mathrm{~km}$ distant-and arrived on Zhokhov Island c. 8000 BP. The archaeological data from Zhokhov therefore indicate a super-long-distance Mesolithic exchange network.

Keywords: Siberia, Zhokhov Island, Early Holocene, obsidian, provenancing, transport and exchange

1 Institute for Material Culture History, Russian Academy of Sciences, Dvortsovaya Embankment 18, St Petersburg 191186, Russia

2 Sobolev Institute of Geology \& Mineralogy, Siberian Branch of the Russian Academy of Sciences, Koptyug Avenue 3, Novosibirsk 630090, Russia

3 Laboratory of Mesozoic \& Cenozoic Continental Ecosystems, Tomsk State University, Lenin Avenue 36, Tomsk 634050, Russia

4 Archaeometry Laboratory, University of Missouri Research Reactor, 1513 Research Park Drive, Columbia, MO 65211, USA

5 Arctic \& Antarctic Research Institute, Bering Street 38, St Petersburg 199397, Russia

6 Far Eastern Geological Institute, Far Eastern Branch of the Russian Academy of Sciences, 100-Letiya Vladivostoku Avenue 159, Vladivostok 690022, Russia

7 Far Eastern Federal University, Sukhanov Street 8, Vladivostok 690950, Russia

* Authors for correspondence (Email: pitulkov@gmail.com; kuzmin@fulbrightmail.org)

(C) Antiquity Publications Ltd, 2019

ANTIQUITY 93367 (2019): 28-44

https://doi.org/10.15184/aqy.2019.2 


\section{Introduction}

Provenancing obsidian facilitates the study of the procurement and exchange of this valuable raw material with a high degree of certainty (e.g. Shackley 2005). It can also be used indirectly to document prehistoric human migrations. Such studies have been conducted in eastern Russia since the early 1990s (e.g. Kuzmin \& Glascock 2014; Grebennikov \& Kuzmin 2017; Grebennikov et al. 2018) and, today, all the major obsidian sources in this vast region have been sampled and analysed according to international standards (Glascock et al. 1998). This now permits the origins of the obsidian used for any individual artefact to be pinpointed with accuracy.

In mainland north-eastern Siberia, archaeological obsidian is common in the Chukotka and Kamchatka regions, due to the close proximity of primary sources, particularly in the latter territory (Dikov 1997; Kuzmin et al. 2008; Kiryak 2010; Grebennikov \& Kuzmin 2017). Farther west and south-west, the frequency of obsidian artefacts decreases significantly in, for example, the basins of the Kolyma and the Indighirka Rivers, and along the Okhotsk Sea coast (see Kuzmin et al. 2018). The Indighirka River represents the westernmost limit of archaeological obsidian distribution in the continental Siberian Arctic (Fedoseeva 1980).

The discovery in 1989 of an Early Holocene site on Zhokhov Island in the High Arctic$76^{\circ} 08^{\prime}$ north, $152^{\circ} 43^{\prime}$ east-radically changed our understanding of the presence of prehistoric humans north of the Arctic Circle (Makeyev et al. 1992; Pitulko 1993, 2013). The results of several campaigns of excavation undertaken on the island have now been published (Girya \& Pitulko 1994; Pitulko \& Kasparov 1996, 2017; Pitulko 2001, 2003, 2013; Pitulko et al. 2012, 2015; Pitulko \& Pavlova 2015, 2016; Lee et al. 2015, 2018). The present article focuses on obsidian artefacts recovered during excavations in 1989-1990 and in the 2000s (Pitulko \& Makeev 1991; Pitulko 1993: 18; Pitulko et al. 2012). These artefacts provide an opportunity to establish the primary source location(s) for archaeological obsidian recovered from Zhokhov, in order to enhance our understanding of human mobility and the acquisition of raw material in the Siberian Arctic (e.g. Pitulko 2013; Kuzmin 2015). In this article, we present the first results of obsidian provenancing for the insular Siberian Arctic- one of the most remote regions of the world to have yielded archaeological materials.

\section{The Zhokhov site}

The Zhokhov site is located on Zhokhov Island, part of the De Long group of the New Siberian Islands (Figure 1). Systematic investigation of the site began in 1989-1990 (e.g. Makeev et al. 1992; Pitulko 1993, 2003; Pitulko \& Kasparov 1996), and a large-scale study took place from 2000-2005 (Pitulko et al. 2012, 2015). The total excavated area $\left(571 \mathrm{~m}^{2}\right)$ is divided into zones 1-3 (northern, central and southern, respectively; see Figure 2). The Zhokhov archaeological assemblage comprises approximately 19160 lithic artefacts; over 54000 faunal elements (around 22000 are identifiable to species); more than 300 objects made of antler, mammoth ivory and bone; approximately 1000 items made of wood; and a few woven and birch bark artefacts. According to lithic typology and chronology, the Zhokhov site can be associated with the Mesolithic Sumnagin cultural complex, which was widely distributed across northern Siberia (e.g. Pitulko 2001). 


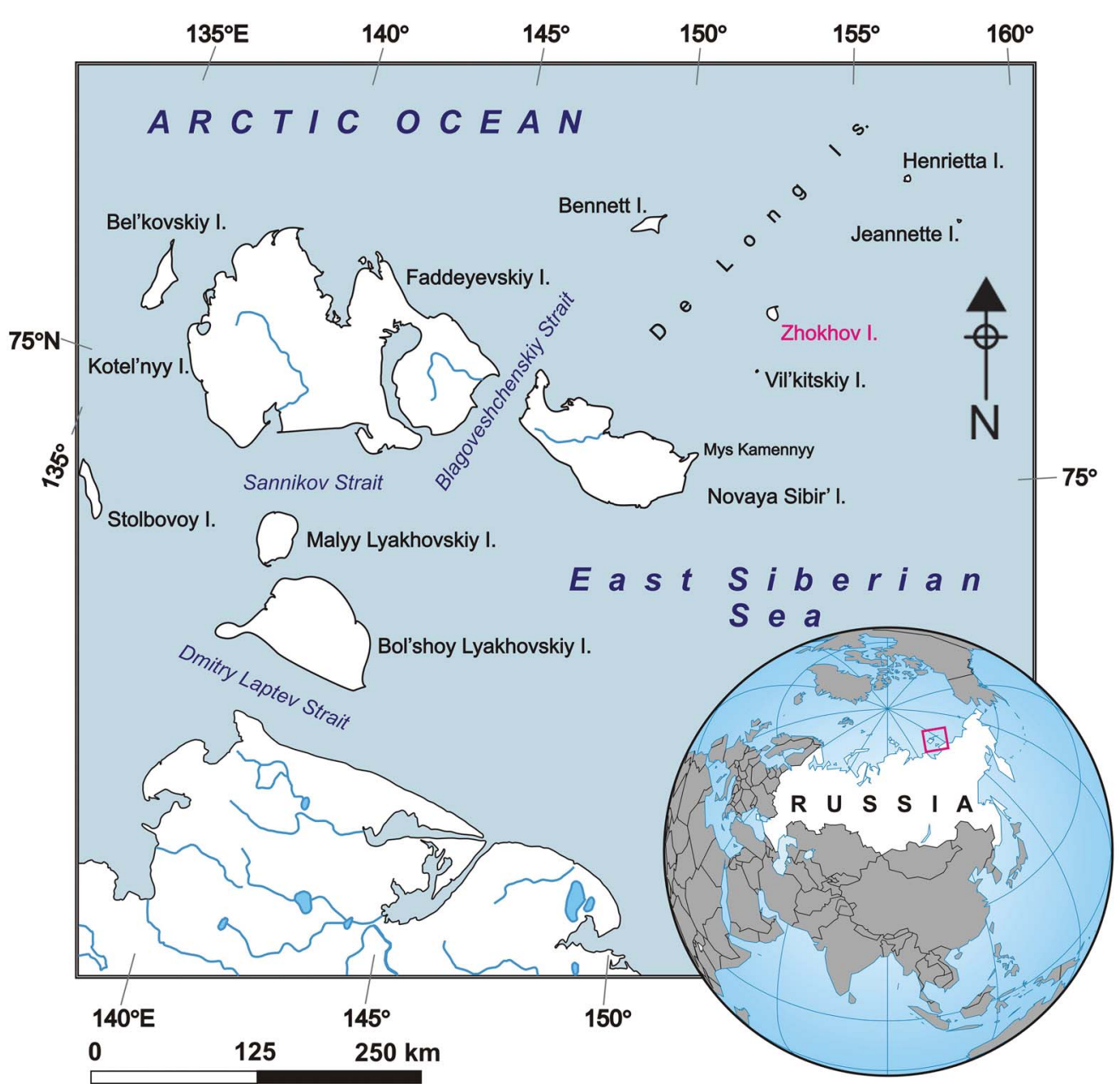

Figure 1. Position of the Zhokhov site and other localities in insular north-eastern Siberia.

It is important to note that during the site's occupation $c .8000-7800 \mathrm{BP}$ (see below), Zhokhov Island was still a part of a dryland zone that is now submerged and forms part of the shelf of the East Siberian Sea (Anisimov et al. 2009); the site was located near the Early Holocene coastline. The lithic assemblage includes 341 cores, 164 blades and blade fragments (greater than $5 \mathrm{~mm}$ wide), 9187 microblades (less than $5 \mathrm{~mm}$ wide) and 90 formal tools (points, arrowheads, chisels and their preforms, mallet-like tools, hammerstones and grindstones) (Pitulko et al. 2012; Pitulko 2013). It is important to note that neither cores nor chisels and adzes were initially made at the site, as there is no related debitage. Compared with the number of cores, the presence of only a few pieces of unworked raw material $(n=3)$ suggests that the cores were made away from the site and brought in as semi-finished products, and were then finished, used, rejuvenated/reworked and re-used.

The composition of the raw materials recovered from the site is presented in Table 1. Rare ('exotic') rock types are chalcedony and obsidian. The dominant type is flint/chert of brown, (C) Antiquity Publications Ltd, 2019 
'They came from the ends of the earth': long-distance exchange of obsidian in the High Arctic

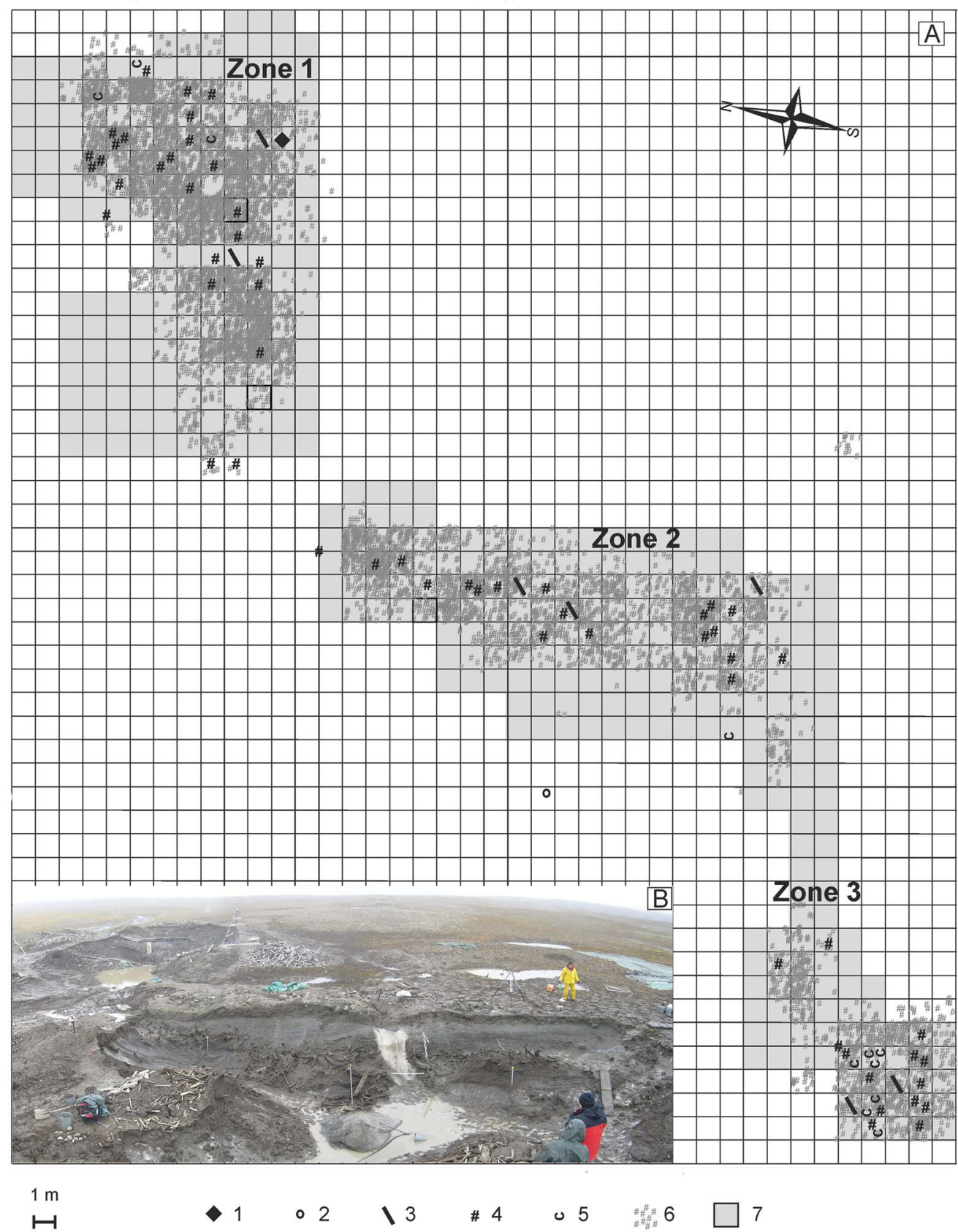

Figure 2. Spatial distribution of obsidian artefacts at the Zhokhov site. A: 1-5 obsidian artefacts: 1) piece of raw material; 2) flake; 3) microblade core; 4) prismatic blade, >5mm wide; 5) microblade, <5mm wide; 6) other lithics (flakes and microblades made of chert, quartzite and chalcedony); 7) excavated grids. B: general view of the excavation, from the west-south-west. 
Table 1. The raw material composition of the Zhokhov site (after Pitulko et al. 2012: 232, with modifications).

\begin{tabular}{lc}
\hline Rock types & Number (\%) \\
\hline Flint & $17210(92.4)$ \\
Sandstone & $1084(5.9)$ \\
Quartzite & $162(0.97)$ \\
Obsidian & $79(0.54)$ \\
Chalcedony & $56(0.3)$ \\
Tuffa-basalt & $7(0.04)$ \\
Quartz & $1(0.01)$ \\
Undetermined & $19(0.1)$ \\
Total & $\mathbf{1 8 6 1 8 ( 1 0 0 . 0 )}$
\end{tabular}

light brown and yellowish-brown colours. It is of local origin and can be found in Zhokhov Island's Quaternary deposits as pebbles and small boulders. Flint similar in colour, nodule size and general quality (by visual examination) is common in the Quaternary sediments at Mys Kamennyy (Stony Cape), which is located on the north-eastern extremity of Novaya Sibir' Island, approximately $180 \mathrm{~km}$ south of Zhokhov (Basilyan \& Nikolskiy 2007), and on the northern shore of Faddeyevskiy Island, around $250 \mathrm{~km}$ to the south-west (Figure 1).

Analysis of the faunal remains allows for reconstruction of the subsistence strategies practised by the inhabitants of the Zhokhov site (e.g. Pitulko et al. 2015). This demonstrates an unusual adaptation based on the mass procurement of reindeer and polar bear, in an overall ratio of 2:1. Seasonality studies, however, suggest intra-annual variation (Pitulko et al. 2015). The site functioned as a year-round base camp (although summer activity was limited): in winter, people hunted polar bears (mostly females) by taking them from their dens; in the spring and autumn, the hunting of reindeer was the main subsistence activity, involving travel around the vast territory of the present-day New Siberian Archipelago (Pitulko et al. 2015), as is also indicated by raw material use (see above). Analysis of canid remains and associated ancient DNA (Lee et al. 2015; Pitulko \& Kasparov 2017) show that people at the Zhokhov site kept fully domesticated dogs (Canis familiaris) for use both in hunting and as draught animals.

Over 90 radiocarbon dates have been obtained so far on different material from the cultural layer of the Zhokhov site, including driftwood, charcoal and charred wood, plant remains; animal bone, hair and excrement and human bone. Analysis of the radiocarbon dataset (Pitulko \& Pavlova 2015) demonstrates that the main period of occupation ranged from $c .8250 \mathrm{BP}$ to $c .7800 \mathrm{BP}$, with possible later ephemeral visits $c .7700-7400 \mathrm{BP}$; the peak of human activity at the site dates to $c$. 8000-7900 BP.

\section{Obsidian artefacts from the Zhokhov site and their geochemical analysis}

The assemblage of obsidian artefacts from the Zhokhov site comprises 79 items (Pitulko et al. 2012: 232): 59 microblades, 12 flakes (nine of them small), seven blades and one blade

(C) Antiquity Publications Ltd, 2019 

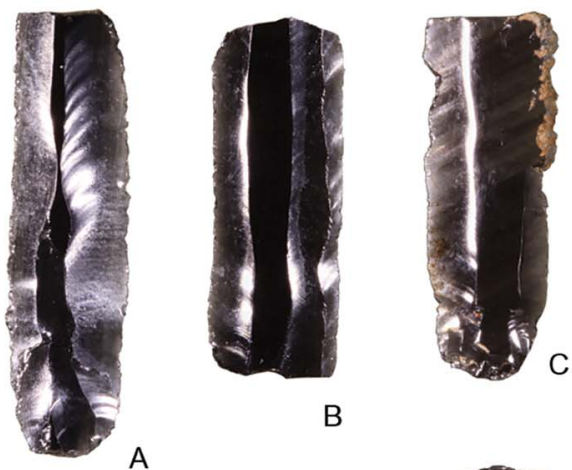

B

A
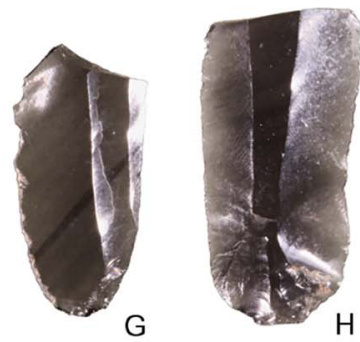

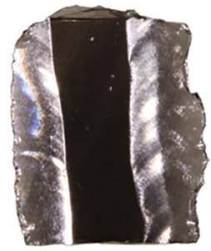

$\mathrm{D}$
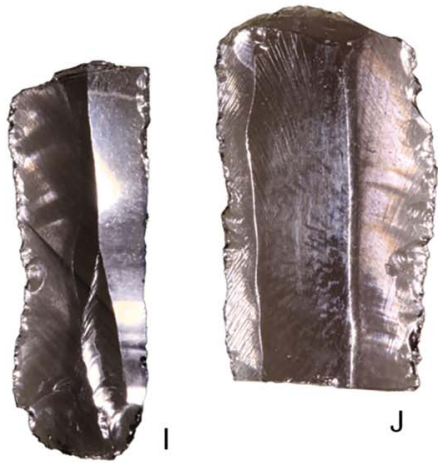

$\mathrm{J}$

20
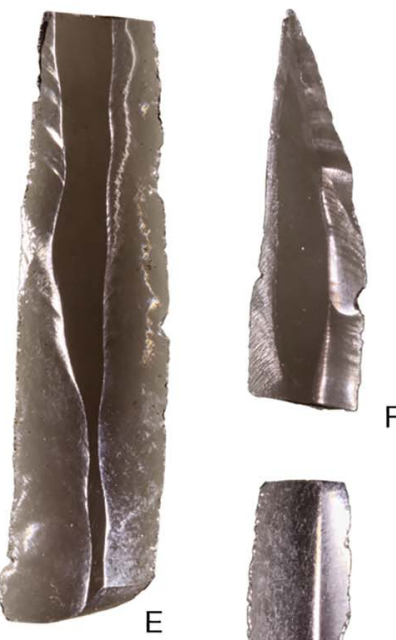

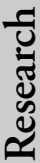

$30 \mathrm{~mm}$

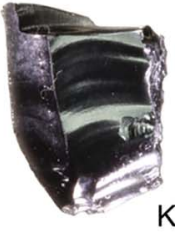

I

Figure 3. Obsidian artefacts (microblades) from the Zhokhov site (numbers correspond to those in the collection's inventory): A) 641, fragmented microblade; B) 3192, medial fragment; C) 2965, proximal part; D) 2428, medial fragment with truncation; E) 1055, medial fragment (one of the longest in the lithic collection); F) 3350, distal fragment; G) 3858, proximal fragment; H) 2153, proximal fragment; I) 133, proximal fragment; J) 923, medial fragment; K) 3661, proximal fragment; L) 336, medial fragment (side microblade).

fragment. This represents 0.54 per cent of the total lithics from the site. Some of the obsidian artefacts have edge retouch that could be the result either of deliberate human action or of post-depositional taphonomy. The straight profile of the microblades indicates that they were made by pressure flaking. In the absence of large obsidian tools, cores and waste products, and cortex on flakes, we can assume that this 'exotic' raw material was brought to the site as preforms. Nevertheless, obsidian items had no special function and were used in the same manner as the dominant raw material types-namely, flint, sandstone and quartzite (Table 1). In comparison with the number of obsidian blades and microblades, the small quantity of flakes can be explained by the fact that they appear as a result of core-maintenance operations, such as platform rejuvenation and preparation of the knapping surface. In general, the size of raw material at the Zhokhov site is small-around $40 \mathrm{~mm}$ long and very rarely up to $60-70 \mathrm{~mm}$; the sizes of obsidian blades and microblades are in accordance with these dimensions.

Fourteen randomly selected obsidian artefacts with relatively flat surfaces were analysed to identify their provenance (Figures 3-4). These were numbers 641, 1220, 2153, 3197, 3777 and 3858 from zone 1; numbers 133, 923, 2428 and 2965 from zone 2; and numbers 336,

(C) Antiquity Publications Ltd, 2019 

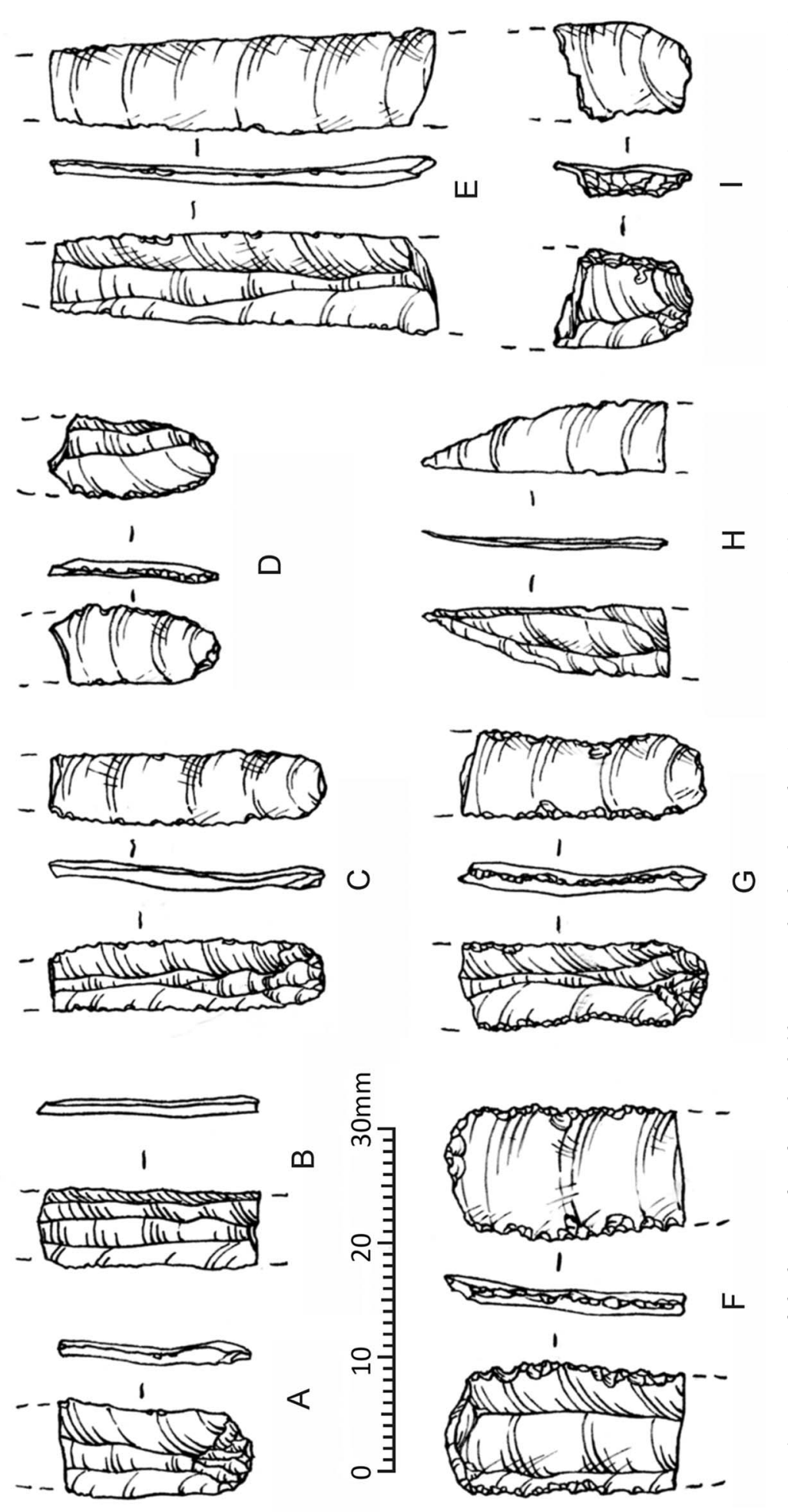

(C) Antiquity Publications Ltd, 2019

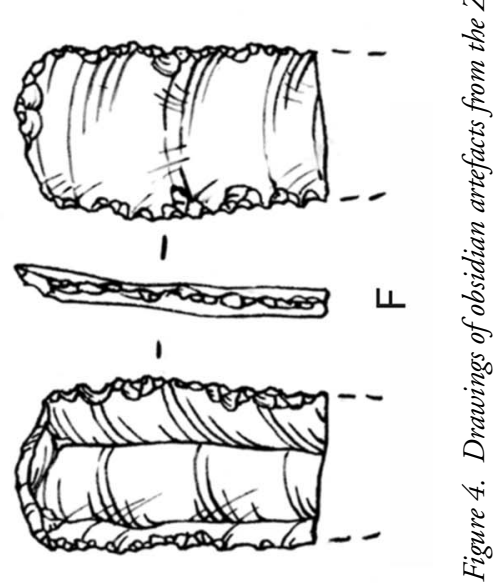


1055,3350 and 3661 from zone 3. Some of these artefacts have edge retouch, which suggests that they were used as side microblades for the inset tools widely known from the Zhokhov complex (Pitulko 2013).

The selected artefacts were examined using non-destructive X-ray fluorescence (XRF) (e.g. Shackley 2011). The analysis was undertaken at the Archaeometry Laboratory, University of Missouri Research Reactor (MURR). The XRF measurements were taken using a ThermoScientific ARL Quantx Energy-Dispersive XRF spectrometer. The instrument has a rhodium-based X-ray tube and thermoelectrically cooled silicon-drift detector (SDD). The tube was operated at $35 \mathrm{kV}$, and current was automatically adjusted to a fixed 30 per cent deadtime for each item. The artefacts were counted for two minutes to measure the content of manganese $(\mathrm{Mn})$, iron $(\mathrm{Fe})$, zinc $(\mathrm{Zn})$, rubidium $(\mathrm{Rb})$, strontium $(\mathrm{Sr})$, yttrium $(\mathrm{Y})$, zirconium $(\mathrm{Zr})$, niobium $(\mathrm{Nb})$ and thorium $(\mathrm{Th})$ (Table 2). Normalisation to the Compton scattering peak was used to account for differences in sample size and thickness. The XRF instrument was calibrated for obsidian by measuring a set of 40 well-characterised obsidian source samples previously analysed by neutron activation analysis (NAA), XRF and inductively coupled plasma-mass spectrometry (ICP-MS), as reported by Glascock and Ferguson (2012).

The results of XRF analysis were compared with data on the geochemical composition of primary obsidian sources from the Kamchatka and Chukotka regions. All specimens from primary sources were tested by NAA at the MURR (see Glascock et al. 2007), and a comprehensive geochemical signature for each source, based on the composition of 28 elements, was established (e.g. Grebennikov \& Kuzmin 2017; Grebennikov et al. 2018). Following this, it was possible to use the smaller number of elements measured by XRF to detect the primary obsidian locale from which the archaeological obsidian originated. This approach has been successfully applied in eastern Russia and elsewhere (e.g. Glascock et al. 1998, 2007; Kuzmin \& Glascock 2014). Statistical grouping based on bivariate plots, and cluster and discriminant classification analyses, was performed using the GAUSS software (available from the MURR at http://archaeometry.missouri.edu/datasets/GAUSS_download.html) to indicate the obsidian sources with greater than 90 per cent probability (Glascock et al. 1998).

\section{Results and discussion}

Geochemical data on artefacts from the Zhokhov site were compared to known primary obsidian sources from the Chukotka and Kamchatka regions (see Grebennikov et al. 2018), through the analysis of scatterplots of different pairs of elements; the most definitive plots are $\mathrm{Rb} v s \mathrm{Sr}$ and $\mathrm{Mn} v s \mathrm{Y}$ (Figure 5). The geochemistry of the Zhokhov artefacts is in good agreement with the 90 per cent confidence ellipse for the Cape Medvezhiy source, at Lake Krasnoe in the Chukotka region (group KRASN-1 in Grebennikov et al. 2018) (see Figure 5B \& Table 2). This result indicates the super-long-distance movement of obsidian from the source to the utilisation site-approximately $1500 \mathrm{~km}$ as the crow flies. While archaeological obsidians are well known in and around the Anadyr River valley (Dikov 1997; Kiryak 2010), there are only a few localities where such artefacts are known elsewhere in the north-eastern Siberian Arctic, between the Chukotka source area and the Zhokhov site. These are poorly dated surface and in situ contexts of Holocene age-namely Belaya Gora

(C) Antiquity Publications Ltd, 2019 
Table 2. Mean and standard deviations for obsidian elemental composition measured by XRF from the Zhokhov site (this study) and the Chukotkan sources (after Grebenikov et al. 2018).

\begin{tabular}{lccccc}
\hline Element* & $\begin{array}{c}\text { Zhokhov site } \\
(\mathbf{n}=\mathbf{1 4})\end{array}$ & $\begin{array}{c}\text { KRASN-1 } \\
(\mathbf{n}=\mathbf{3 3})\end{array}$ & $\begin{array}{c}\text { KRASN-2 } \\
(\mathbf{n}=\mathbf{8})\end{array}$ & $\begin{array}{c}\text { KRASN-3 } \\
(\mathbf{n}=\mathbf{1})\end{array}$ & $\begin{array}{c}\text { Vakarevo type } \\
(\mathbf{n}=5)\end{array}$ \\
\hline $\mathrm{Mn}$ & $253 \pm 4$ & $176 \pm 61$ & $221 \pm 5$ & 560 & $247 \pm 39$ \\
$\mathrm{Fe}(\%)$ & $0.76 \pm 0.06$ & $0.64 \pm 0.03$ & $1.11 \pm 0.24$ & 1.88 & $0.96 \pm 0.04$ \\
$\mathrm{Zn}$ & $56 \pm 6$ & $63 \pm 16$ & $112 \pm 14$ & 113 & $65 \pm 15$ \\
$\mathrm{Rb}$ & $220 \pm 9$ & $193 \pm 8$ & $144 \pm 6$ & 128 & $146 \pm 3$ \\
$\mathrm{Sr}$ & $3.0 \pm 0.4$ & $2.3 \pm 0.8$ & $1.3 \pm 0.7$ & 39 & $35 \pm 2$ \\
$\mathrm{Y}$ & $59 \pm 2$ & $54 \pm 3$ & $83 \pm 4$ & 56 & $41 \pm 2$ \\
$\mathrm{Zr}$ & $124 \pm 3$ & $116 \pm 6$ & $439 \pm 12$ & 451 & $135 \pm 3$ \\
$\mathrm{Nb}$ & $8.7 \pm 0.4$ & $7.3 \pm 1.6$ & $123.9 \pm 1.3$ & 8.3 & $5.7 \pm 2.1$ \\
$\mathrm{Th}$ & $17.4 \pm 0.8$ & $16.5 \pm 2.2$ & $14.1 \pm 2.2$ & 13.7 & $13.1 \pm 1.4$ \\
\hline
\end{tabular}

* Content in parts-per-million (ppm), unless otherwise indicated.

in the Indighirka River basin, Starye Petushki and Konzaboi, Pomazkino, Rodinka and Labuya in the Kolyma River basin and the Lake Tytyl cluster of sites in western Chukotka (Fedoseeva 1980; Kiryak 2010; Kashin 2013).

It is unlikely that the inhabitants of the Zhokhov site procured obsidian directly from the Lake Krasnoe source. It lies far beyond the maximum direct supply zone for resources (around $300 \mathrm{~km}$ ) proposed by Renfrew (1975), and the obsidian is therefore most likely to have been acquired through exchange. Importantly, according to Renfrew's (1975) model, the transportation of resources, which is assumed to have occurred on foot, could not have been over distances greater than $300 \mathrm{~km}$ (taking 7-10 days one way). In winter time, such a journey required particular skills and technology, such as skiing or the use of snow shoes, both of which were common elsewhere in the Arctic from at least the Early Holocene (Weinstock 2005). While journeys on foot were costly in terms of time, labour and energy, walking allowed for the creation of an exchange network, the scale of which could be expanded significantly by the use of transportation, such as watercraft or animal-powered systems. In both the prehistoric and modern Arctic, the latter is evidenced by sledges pulled by dogs or reindeer. The most suitable season for the use of animals for transport during the occupation of the Zhokhov site would probably have been in early spring (March and April), when snow is still solid and the days are longer than in the winter. Indeed, today, the popular Beringia dog-sled race-a super-long-distance expedition of over $1000 \mathrm{~km}$ —normally takes place during this time of the year.

The Zhokhov site has yielded the world's oldest evidence for wooden sledge runners and other sledge component parts (Pitulko \& Kasparov 1996; Pitulko 2013) (Figure 6). Reconstructions from faunal remains of canine body weight and size show that these animals were similar to modern Siberian huskies (Pitulko \& Kasparov 2017). Sledge transport formed an important part of the subsistence technology of the Zhokhov site's inhabitants. It also should be stressed that these people were skilled travellers, who regularly visited today's New Siberia, Faddeyevskiy and Kotel'nyy Islands to the south and west of the site-as indicated by the presence of raw materials procured from these locations.

(C) Antiquity Publications Ltd, 2019 

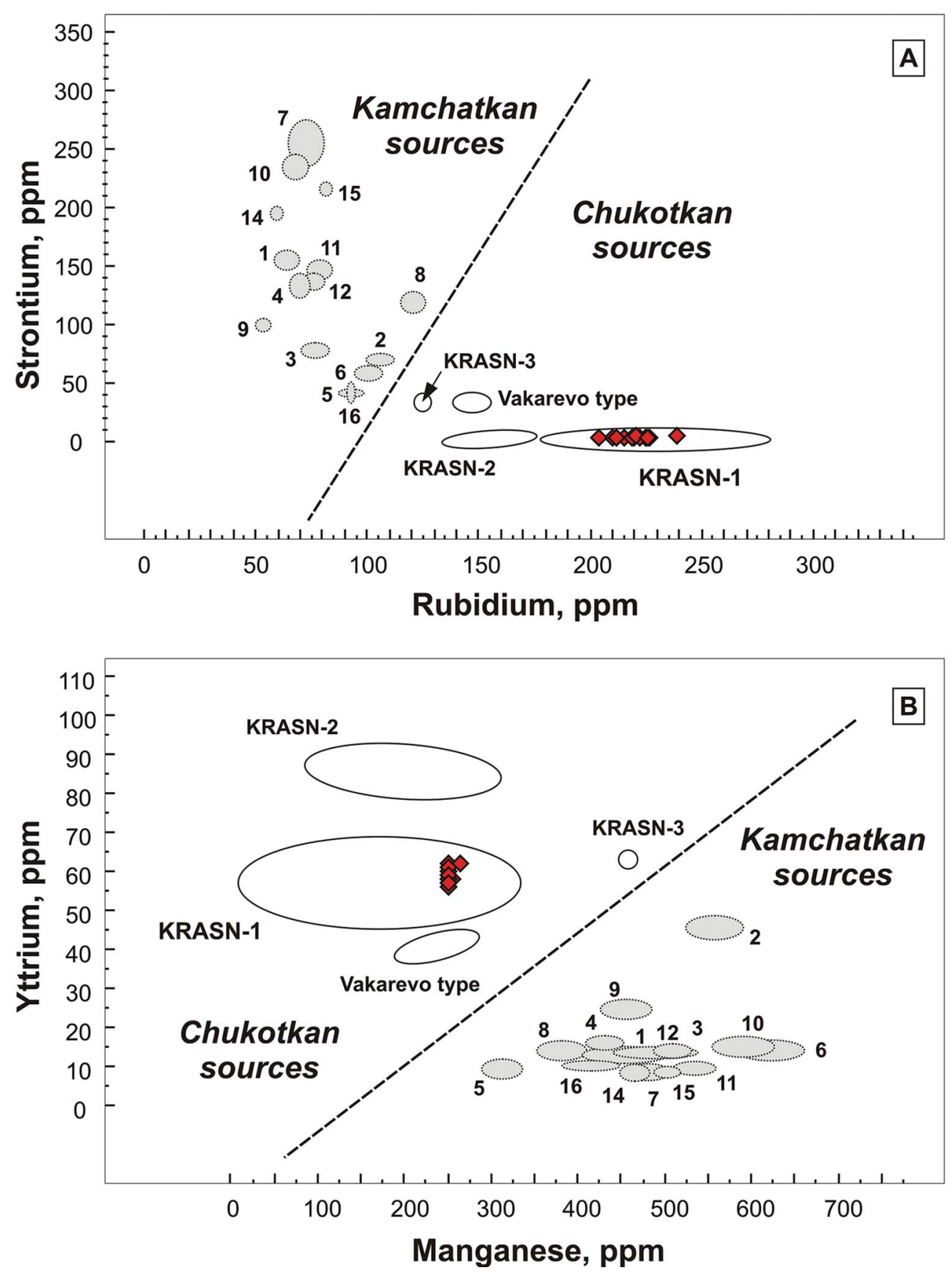

Figure 5. Bivariate plots of NAA and XRF for the artefacts from the Zhokhov site (red diamonds) and obsidian sources on Chukotka and Kamchatka (numbers for Kamchatkan sources correspond to those of KAM groups, see Grebennikov \& Kuzmin 2017). Ellipses are 90 per cent confidence areas. A) Rb. vs Sr;B) $M n$ vs $Y$. 


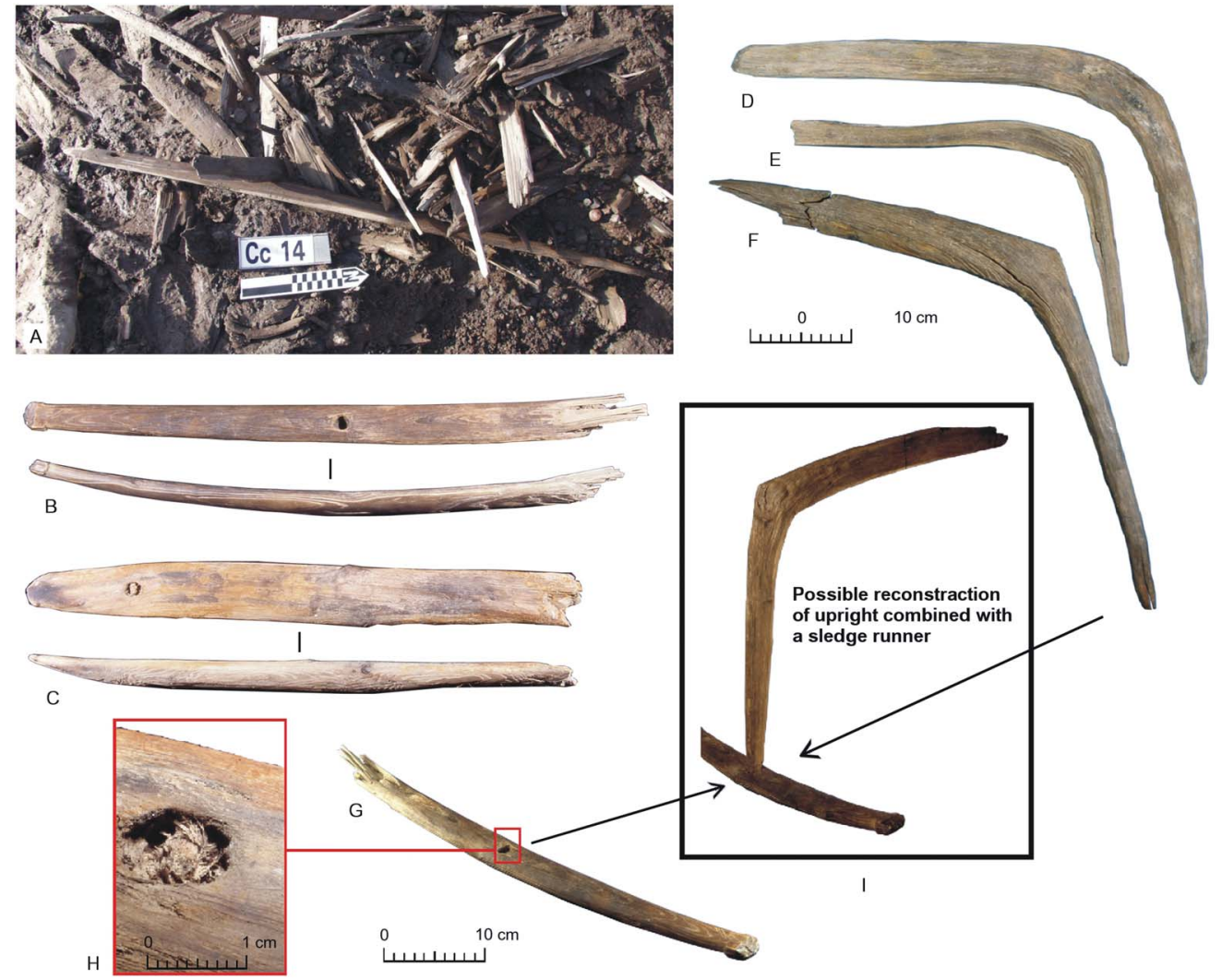

Figure 6. Sledge parts excavated from the Zhokhov site: A) sledge runner as found in situ; B) sledge runner fragment; $C$ ) sledge runner; D) upright; $E$ ) upright; $F$ ) upright; $G$ ) sledge runner fragment ( $B$, other side); $H$ ) hole with a piece of rope made of animal hair (enlarged detail of $G$ ); I) possible reconstruction in which upright $(F)$ is combined with a sledge runner $(G)$.

To understand better the transportation routes for the obsidian found at the Zhokhov site, it is important to consider the regional palaeoenvironmental situation c. 8300-7800 BP. At the Postglacial end of the Pleistocene (c. 15 000-10 000 BP), today's insular Siberian Arctic was part of a vast coastal plain extending $100 \mathrm{~km}$ to the north of the modern coastline (Figure 7). The modern sea depth in this region rarely exceeds $50 \mathrm{~m}$ and is even shallower around Zhokhov Island-between Vil'kitskiy and Zhokhov Islands, for example, the depth is only approximately $20 \mathrm{~m}$ (Pitulko et al. 2015). The process of inundation during the Holocene was complex, and several reconstructions have been proposed (e.g. Bauch et al. 2001; Gavrilov et al. 2006; Anisimov et al. 2009). Some of these, however, do not take into account seabed topography; according to Bauch et al. (2001), for example, Zhokhov was already an island at the time of its human occupation. Our data show that from $c .10600$ $\mathrm{BP}$, Zhokhov Island was situated on the margin of the shrinking Arctic coast (Anisimov et al. 2009) (see Figure 7); this is supported by the presence of a large quantity of driftwood that washed ashore at the Zhokhov site. The environmental situation was relatively favourable for human occupation: the climate was warmer than today, and Zhokhov Island was covered (C) Antiquity Publications Ltd, 2019 


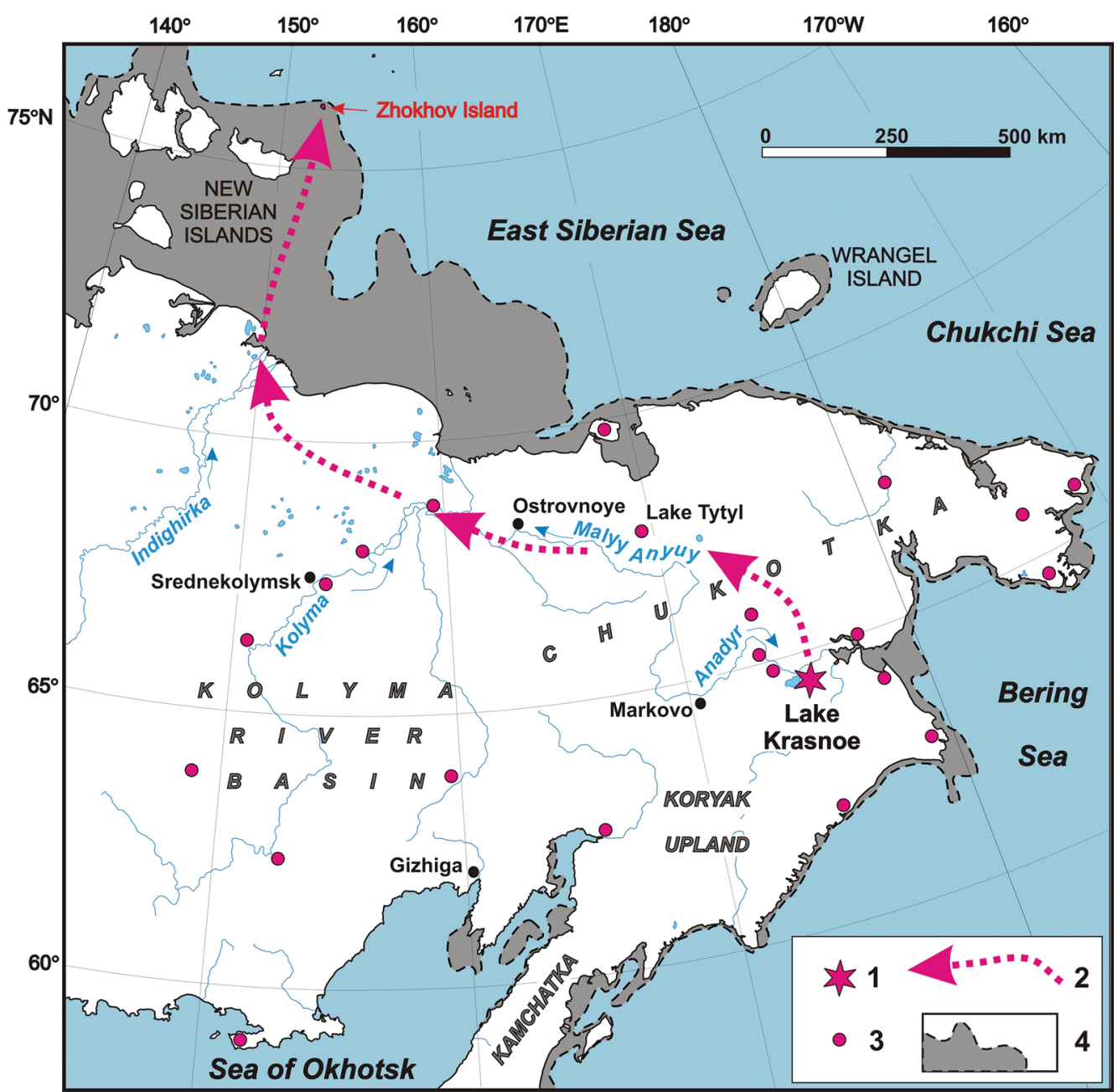

Figure 7. The eastern Siberian Arctic in the Early Holocene and possible ways of obsidian transportation to the Zhokhov site. Approximate position of the coastline at c. 8000 BP is based on Anisimov et al. (2009) and Manley (2002). 1) Primary obsidian source; 2) possible route of obsidian transportation to the Zhokhov site; 3) selected sites with obsidian from the Lake Krasnoe source (after Grebennikov et al. 2018; Kuzmin et al. 2018); 4) exposed shelf (by grey colour) during the occupation of the Zhokhov site, dashed line-coastline at c. 8000 BP.

by an Arctic tundra comprising sedge grass, shrubs and dwarf birch (Makeyev et al. 2003). These open landscapes formed an essential part of the subsistence strategy, as they provided an excellent opportunity for long-distance travel in winter. Around 7800 BP, however, the land between today's island and the mainland was inundated. This corresponds with the end of the site's main occupation by humans. Horse bone from Vil'kitskiy Island dating to $7900 \pm 40 \mathrm{BP}$ (Beta-191338) signifies the end of any connection of the De Long Islands to the mainland; as horses could not swim between islands, they must have arrived prior to insularisation.

The inhabitants of the Zhokhov site clearly visited today's Arctic mainland during the Early Holocene. It is possible that some types of 'trade hub' existed in the Siberian Arctic

(C) Antiquity Publications Ltd, 2019 
for the exchange of valuable resources, such as stone raw materials, furs and other items. The existence of the Ostrovnoye (or Ostrownoje) fair in the Malyy Anyuy River valley (Figure 7) during the seventeenth to nineteenth centuries $\mathrm{AD}$ is noteworthy (von Wrangell 1840). This was a large-scale (by regional standards) event, in which both indigenous people and Russian merchants took part (Vakhtin et al. 2004). According to observations by Russian explorers (see von Wrangell 1840: 114-28), native inhabitants from across north-eastern Siberia gathered here for trade in the early spring, coming from as far as Srednekolymsk in the Kolyma River basin, Gizhiga on the northern shore of the Sea of Okhotsk and Markovo in the Anadyr River basin of Chukotka (Figure 7). The distance between these localities is approximately $450-600 \mathrm{~km}$ in a direct line, and the area covered between them is around $1200000 \mathrm{~km}^{2}$. Contemporaneous fairs of secondary importance existed near the mouth of the Kolyma River, and in the Anadyr River basin, near the modern town of Markovo (Vakhtin et al. 2004).

Although this analogy for long-distance travel and exchange is remote in time, it can be used, with certain reservations, for dog-sled technology, the environment and phenology have remained largely the same in the East Siberian Arctic regions for millennia, regardless of developments such as the introduction of metals, pottery or other innovations. Dog-sled technology undoubtedly played an important part in raw materials exchange networks, as evidenced by the presence of Chukotkan obsidian at the Zhokhov site. Although virtually no obsidian has been found in the Early Holocene archaeological record between the Zhokhov site and Chukotka, a connection between these two areas clearly existed by $c .8000 \mathrm{BP}$. This region in between them, however, is largely unexplored archaeologically (see Pitulko \& Pavlova 2016).

It is notable that Mid and Late Holocene obsidian artefacts have been found in the Malyy Anyuy River basin (in western Chukotka) and in the lower course of the Kolyma River (Fedoseeva 1980; Kiryak 2010; Kashin 2013); provenance determination shows that obsidian originated from the single source at Lake Krasnoe. Thus, the existence of a Late Holocene ( $c$. 3000-4000 BP) long-distance exchange system in north-eastern Siberia can be assumed (e.g. Grebennikov et al. 2018; Kuzmin et al. 2018). Although poorly documented in the archaeological record, such an exchange system is suggested, for instance, by the appearance of metal tools in Chukotka (e.g. Arutiunov \& Sergeev 2006).

Obsidian is more frequently encountered at the Malyy Anyuy River sites than in the Kolyma River locales, and the presence of formal tools (some with cortex) and debitage is recorded for the former region (see Kiryak 2010). It is possible that raw obsidian was transported to the Malyy Anyuy River basin in the Middle-Late Holocene (Neolithic and Bronze Age) as unmodified nodules; the distance between the Lake Krasnoe source and utilisation sites is around $450-500 \mathrm{~km}$ in a direct line. Fewer obsidian artefacts are found in and around the Kolyma River mouth, which is approximately $850 \mathrm{~km}$ from the source (Figure 7).

Following the theories concerning the mechanisms of obsidian acquisition (Renfrew 1975; Renfrew \& Dixon 1976), it is possible to assume that the inhabitants of Zhokhov Island, who were located well beyond the $300 \mathrm{~km}$ 'supply zone', obtained this raw material by down-the-line trade or exchange. Some of the 'hubs' for this activity could have been situated in the Malyy Anyuy River basin and near the mouth of the Kolyma River, where several Early Holocene sites (e.g. the Lake Tytyl cluster; Figure 7) with obsidian are known

(C) Antiquity Publications Ltd, 2019 
(Fedoseeva 1980; Kiryak 2010; Kashin 2013). Early Holocene super-long-distance obsidian exchange in the High Arctic is now scientifically demonstrated. Such an exchange system is a remarkable example of a subsistence strategy in use in northern Siberia at that time, if not earlier. The presence of other Mesolithic sites on the north-eastern Siberian Arctic mainland (Pitulko \& Pavlova 2015) testify—indirectly— to the active contact between human groups across this region.

New data about the penetration of Lake Krasnoe obsidian into the High Arctic at approximately 8250-7800 BP are a valuable addition to the existing knowledge on the extremely wide distribution of this raw material around north-eastern Siberia and northern North America, including Chukotka, the Koryak Upland, the Kolyma River basin, the northern coast of the Okhotsk Sea and St Lawrence Island and mainland Alaska (see Grebennikov et al. 2018; Kuzmin et al. 2018).

\section{Conclusions}

For the first time in the Siberian High Arctic, obsidian artefacts from the Early Holocene Zhokhov site have been provenanced. The results show that this valuable raw material was acquired from the area of Lake Krasnoe in Chukotka, approximately $1500 \mathrm{~km}$ away from the place of use. It is unlikely that the inhabitants of the Zhokhov site travelled this enormous distance to obtain the obsidian directly and instead participated in a long-distance exchange or trade network. Thus, we suggest that the Early Holocene people of the north-eastern Siberian Arctic maintained a well-developed network, which facilitated the exchange and transmission of information and knowledge, and covered a vast region of up to $4000000 \mathrm{~km}^{2}$. Surprisingly, the capacity of prehistoric people to cover large distances and communicate with each other was almost as effective as historical communication systems known in other similar parts of the world. Its high efficiency was based on the combination of suitable environment-open tundra landscapes, with snow cover and frozen north-south rivers in winter and early spring-and well-developed sledge technology. Prehistoric people 'came from the ends of the earth' to obtain exotic raw materials, via a network that could have continued to exist in the north-eastern Siberian Arctic throughout the Holocene and into historical times.

\section{Acknowledgements}

This study began in 1989-1990 as a part of long-term investigation of the New Siberian Islands by the Institute for the History of Material Culture and Arctic \& Antarctic Research Institute. It was continued from 2002-2005 as a part of the Zhokhov-2000 Project, supported by the Rock Foundation of New York. At present, it is a part of the Russian Government Research Project 0184-2018-0011. It was supported by the Russian Science Foundation through the project 16-18-10265 RNF granted to V.V. Pitulko, and also by the U.S. Civil Research and Development Foundation (RG1-2538-VL-03, RUG1-7097-NO-13) for Y.V. Kuzmin and A.V. Grebennikov; by the U.S. National Science Foundation (NSF-1621158) for MURR; and by the Tomsk State University Competitiveness Improvement Program and State Assignment Project (0330-2016-2018) for Y.V. Kuzmin. The authors are grateful to the Zhokhov-2000 excavation team. Special thanks go to E.P. Savchenko (logistics), N.V. Abdulmanova (graphic drawings) and P.I. Ivanov (photography). We thank two anonymous reviewers for useful comments. 


\section{References}

Anisimov, M.A., V.V. Ivanova, Z.V. Pushina \& V.V. Pitulko. 2009. Lagoon deposits of the Jokhov Island: age, conditions of formation and meanings for paleogeographical reconstructions of the region of Novosibirsk Islands. Izvestiya Rossiiskoi Akademii Nauk, Seriya Geograficheskaya 5: 107-19 (in Russian).

Arutiunov, S.A. \& D.A. Sergeev. 2006. Ancient cultures of the Asiatic Eskimos: the Uelen cemetery. Anchorage (AK): Shared Beringian Heritage Program.

Basilyan, A.E. \& P.A. Nikolskiy. 2007. The key section of the Quaternary deposits at the Cape Kamenny (New Siberia Island). Bulleten Komissii po Izucheniyu Chetrevtichnogo Perioda 67: 76-84 (in Russian).

Bauch, H.A., T. Mueller-Lupp, E. Taldenkova, L.F. Spielhagen, H. Kassens, P.M. Grootes, J. Thiede, J. Heinemeier \& V.V. Petryashov. 2001. Chronology of the Holocene transgression at the North Siberian margin. Global and Planetary Change 31: 125-39. https://doi.org/10.1016/S0921-8181(01) 00116-3

Dikov, N.N. 1997. Asia at the juncture with America in antiquity: the Stone Age of the Chukchi Peninsula. Anchorage (AK): Shared Beringian Heritage Program.

Fedoseeva, S.A. 1980. Ymyyakhtakhskaya kultura Severo-Vostochnoi Azii. Novosibirsk: Nauka (in Russian).

GaVrilov, A.V., N.N. RomanovskiI \& H.-W. Hubberten. 2006. Paleogeographic scenario of the postglacial transgression on the Laptev Sea shelf. Kriosfera Zemli 10: 39-50 (in Russian).

Girya, E. Yu. \& V.V. Pitulko. 1994. High Arctic Mesolithic culture of Zhokhov Island: insert tools and knapping technology. Arctic Anthropology 31 (2): 17-29.

Glascock, M.D. \& J.R. Ferguson. 2012. Report on the analysis of obsidian source samples by multiple analytical methods. Unpublished manuscript available upon request from the Archaeometry Laboratory, The University of Missouri.

Glascock, M.D., G.E. Braswell \& R.H. Cobean. 1998. A systematic approach to obsidian source characterization, in M.S. Shackley (ed.)

Archaeological obsidian studies: method and theory: 15-65. New York: Springer.

Glascock, M.D., R.J. Speakman \& H. Neff. 2007. Archaeometry at the University of Missouri

Research Reactor and the provenance of obsidian artefacts in North America. Archaeometry 49: 353-67.

https://doi.org/10.1111/j.1475-4754.2007. 00305.x

Grebennikov, A.V. \& Y.V. Kuzmin. 2017. The identification of archaeological obsidian sources on Kamchatka Peninsula (Russian Far East) using geochemical and geological data: current progress. Quaternary International 442B: 95-103. https://doi.org/10.1016/j.quaint.2016.03.020

Grebennikov, A.V., Y.V. KuZmin, M.D. Glascock, V.K. Popov, S.Y. BudnitskiY, M.A. Dikova \& E.A. Nozdrachev. 2018. The Lake Krasnoe obsidian source in Chukotka (north-eastern Siberia): geological and geochemical frameworks for provenance studies in Beringia. Archaeological and Anthropological Sciences 10: 599-614. https://doi.org/10.1007/s12520-016-0379-z Kashin, V.A. 2013. Neolit srednei Kolymy. Novosibirsk: Nauka (in Russian).

Kiryak (Dikova), M.A. 2010. The Stone Age of Chukotka, north-eastern Siberia (new materials) (British Archaeological Reports International series 2099). Oxford: Archaeopress.

KuZmin, Y.V. 2015. Northern and North-eastern Asia: archaeology, in P.S. Bellwood (ed.) The global prehistory of human migration: 191-96. Chichester: Wiley-Blackwell.

Kuzmin, Y.V. \& M.D. GLascock. 2014. The neutron activation analysis of volcanic glasses in the Russian Far East and neighbouring North-east Asia: a summary of the first 20 years of research, in A. Ono, M.D. Glascock, Y.V. Kuzmin \& Y. Suda (ed.) Methodological issues for characterisation and provenance studies of obsidian in Northeast Asia: 85-93. Oxford: Archaeopress.

KuZmin, Y.V., R.J. Speakman, M.D. Glascock, V.K. Popov, A.V. Grebennikov, M.A. Dikova \& A.V. Ptashinsky. 2008. Obsidian use at the Ushki Lake complex, Kamchatka Peninsula (northeastern Siberia): implications for Terminal Pleistocene and Early Holocene human

(C) Antiquity Publications Ltd, 2019 
migrations in Beringia. Journal of Archaeological Science 35: 2179-87. https://doi.org/10.1016/j.jas.2008.02.001

Kuzmin, Y.V., A.N. Alekseyev, V.M. Dyakonov, A.V. Grebennikov \& M.D. Glascock. 2018. Determination of the source for prehistoric obsidian artifacts from the lower reaches of Kolyma River, northeastern Siberia, Russia, and its wider implications. Quaternary International 476: 95-101.

https://doi.org/10.1016/j.quaint.2018.02.017

Lee, E.J., D.A. Merriwether, A.K. Kasparov,

P.A. Nikolskiy, M.V. Sotnikova, E.

Yu. Pavlova \& V.V. Pitulko. 2015. Ancient DNA analysis of the oldest canid species from the Siberian Arctic and genetic contribution to the domestic dog. PLoS ONE 10: e0125759. https://doi.org/10.1371/journal.pone.0125759

Lee, E.J., D.A. Merriwether, A.K. Kasparov, V.I. Khartanovich, P.A. NikolskiY, F.K. Shidlovskiy, A.V. Gromov, T.A. Chikisheva, V.G. ChasnyK, V.B. Timoshin, E.Y. Pavlova \& V.V. Pitulko. 2018. A genetic perspective of prehistoric hunter-gatherers in the Siberian Arctic: mitochondrial DNA analysis of human remains from 8000 years ago. Journal of Archaeological Science: Reports 17: 943-49.

https://doi.org/10.1016/j.jasrep.2016.06.001

Makeyev, V.M., V.V. Pitulko \& A.K. Kasparov. 1992. Ostrova De-Longa: an analysis of palaeoenvironmental data. Polar Record 28(167): 301-306. https://doi.org/10.1017/S0032247400028035

Makeyev, V.M., D.P. Ponomareva, G.M. Chernova, V.V. Pitulko \& D.V. SolovyeVA. 2003. Vegetation and climate of the New Siberian Islands for the past 15000 years. Arctic, Antarctic and Alpine Research 35: 56-66.

https://doi.org/10.1657/1523-0430(2003)035 [0056:VACOTN]2.0.CO;2

Manley, W.F. 2002. Post-glacial flooding of the Bering Land Bridge: a geospatial animation. INSTAAR, University of Colorado, v. 1. Available at: http://instaar.colorado.edu/qgisl/ bering_land_bridge (accessed 7 January 2019).

Pitulko, V.V. 1993. An Early Holocene site in the Siberian High Arctic. Arctic Anthropology 30: 13-21.
- 2001. Terminal Pleistocene/Early Holocene occupation in North-east Asia and the Zhokhov assemblage. Quaternary Science Reviews 20: 267-75. https://doi.org/10.1016/S0277-3791(00)00117-7

- 2003. The bear-hunters of Zhokhov Island, east Russian Arctic, in J. Habu, J.M. Savelle, S. Koyama \& H. Hongo (ed.) Hunter-gatherers of the north Pacific Rim: 141-52. Osaka: National Museum of Ethnology.

- 2013. The Zhokhov Island site and ancient habitation in the Arctic. Burnaby: SFU Archaeology Press.

Pitulko, V.V. \& A.K. Kasparov. 1996. Ancient Arctic hunters: material culture and survival strategy. Arctic Anthropology 33(1): 1-36.

- 2017. Archaeological dogs from the Early Holocene Zhokhov site in the eastern Siberian Arctic. Journal of Archaeological Science: Reports 13: 491-515. https://doi.org/10.1016/j.jasrep.2017.04.003

Pitulko, V.V. \& V. Makeev. 1991. Ancient Arctic hunters. Nature 349: 374. https://doi.org/10.1038/349374a0

Pitulko, V.V. \& E. Yu. Pavlova. 2015. Radiocarbon dating of culture-bearing deposits of the Zhokhov site (New Siberia Archipelago, Siberian Arctic). Zapiski Instituta Istorii Materialnoi Kultury RAN 12: 27-55 (in Russian).

- 2016. Geoarchaeology and radiocarbon chronology of Stone Age Northeast Asia. College Station: Texas A\&M University Press.

Pitulko, V.V., E. Yu. Pavlova, V.V. Ivanova \& E. Yu. Girya. 2012. The Zhokhov site: geology and stone industry (preliminary report on the excavations of 2000 through 2005). Stratum plus 1: 211-56 (in Russian).

Pitulko, V.V., V.V. Ivanova, A.K. Kasparov \& E. Yu. Pavlova. 2015. Reconstructing prey selection, hunting strategy and seasonality of the Early Holocene frozen site in the Siberian High Arctic: a case study on the Zhokhov site faunal remains, De Long Islands. Environmental Archaeology 20: 120-57. https://doi.org/10.1179/1749631414Y. 0000000040

Renfrew, C. 1975. Trade as action at a distance: questions of integration and communication, in C. Lamberg-Karlovsky (ed.) Ancient civilization and trade: 3-59. Albuquerque: University of $\mathrm{New}$ Mexico Press. 
Renfrew, C. \& J. Dixon. 1976. Obsidian in Western Asia: a review, in G. de G. Sieveking, I.H. Longworth \& K.E. Wilson (ed.) Problems in economic and social archaeology: 137-50. London: Duckworth.

Shackley, M.S. 2005. Obsidian: geology and archaeology in the North American Southwest. Tucson: University of Arizona Press.

- (ed.). 2011. X-ray fluorescence spectrometry (XRF) in geoarchaeology. New York: Springer.
Vakhtin, N.B., E.V. Golovko \& P. Schweitzer. 2004. Russkie starozhily Sibiri: sotsialnye $i$ simvolicheskie aspekty samosoznaniya. Moscow: Novoe Izdatelstvo (in Russian).

VON WRANGELl, F. 1840. Narrative of an expedition to the Polar Sea, in the years 1820, 1821, 1822, \& 1823. London: James Madden \& Co.

Weinstock, J. 2005. The role of skis and skiing in the settlement of early Scandinavia. The Northern Review 25-26: 172-96.

Received: 24 May 2018; Revised: 8 October 2018; Accepted: 9 November 2018

(C) Antiquity Publications Ltd, 2019 